\title{
Contributions of public and private sectors to the Iranian cataract surgery output
}

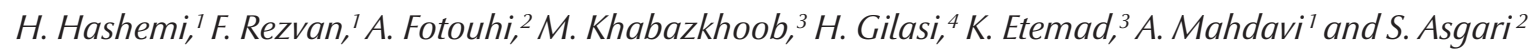

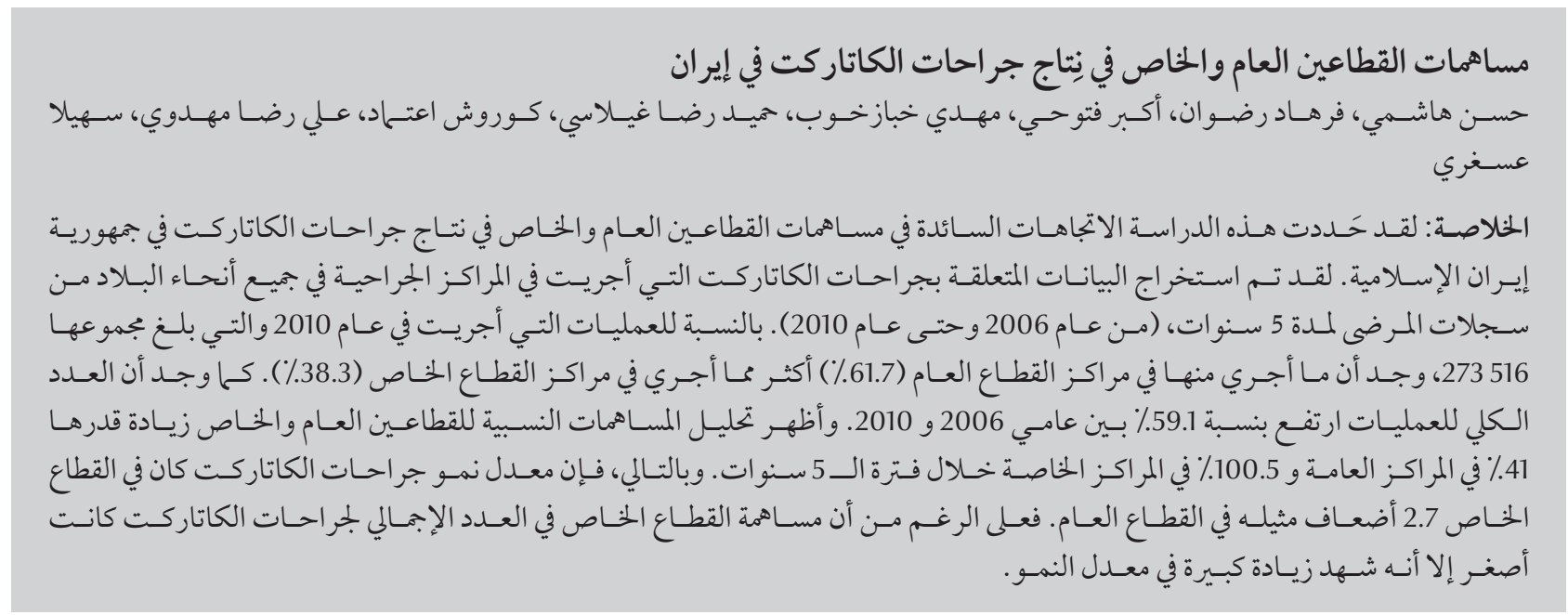

ABSTRACT This study determined trends in the contributions of the public and private sectors to the cataract surgery output in the Islamic Republic of Iran. Data about cataract surgeries performed at surgical centres throughout the nation were extracted from patient charts for a 5-year period from 2006 to 2010. Of the total 516273 surgeries performed in 2010, more were done in public sector centres $(61.7 \%)$ than private ones (38.3\%). The total number of surgeries increased by $59.1 \%$ between 2006 and 2010 . Analysis of the relative contributions of the public and private sectors showed a $41.0 \%$ increase in surgeries in public centres and $100.5 \%$ in private centres over the 5-year period. Thus the rate of growth of cataract surgery in the private sector was 2.7 times greater than that in the public sector. Despite a smaller contribution to the total number of cataract surgeries, the private sector has experienced a substantial rate of growth.

\section{Contribution des secteurs public et privé au nombre de chirurgies de la cataracte en Iran}

RÉSUMÉ La présente étude a déterminé les tendances dans la contribution des secteurs public et privé au nombre de chirurgies de la cataracte en République islamique d'Iran. Les données sur les chirurgies de la cataracte réalisées dans des centres chirurgicaux de l'ensemble du pays ont été extraites des dossiers des patients sur une période de 5 ans, de 2006 à 2010. Sur un total de 516273 chirurgies de la cataracte réalisées en 2010, $61,7 \%$ l'ont été réalisées dans des centres publics contre 38,3\% dans le privé. Le nombre total de chirurgies a augmenté de 59,1\% entre 2006 et 2010. L'analyse de la contribution relative des secteurs public et privé a révélé une hausse de 41,0 \% dans les centres publics et de 100,5\% dans les centres privés sur cinq ans. Le taux d'augmenter de la chirurgie de la cataracte dans le secteur privé était donc 2,7 fois supérieur à celui du secteur public. Malgré une contribution moindre au nombre total de chirurgies de la cataracte, le secteur privé a connu un taux d'augmentation important en la matière.

'Noor Ophthalmology Research Centre, Noor Eye Hospital, Tehran, Islamic Republic of Iran (Correspondence to S. Asgari: soheilaasgari@gmail. com). ${ }^{2}$ Department of Epidemiology and Biostatistics, School of Public Health, Tehran University of Medical Sciences, Tehran, Islamic Republic of Iran. ${ }^{3}$ Department of Epidemiology, Faculty of Public Health, Shahid Beheshti University of Medical Sciences, Tehran, Islamic Republic of Iran. ${ }^{4}$ Department of Public Health and Biostatistics, Faculty of Health, Kashan University of Medical Sciences, Kashan, Islamic Republic of Iran. 


\section{Introduction}

Blindness, which is most commonly caused by cataract, is one of the most important public health problems in the Eastern Mediterranean Region where the mean prevalence of blindness reaches about 1.5\% (1). More than 60\% of the blind people in this Region reside in Afghanistan, Islamic Republic of Iran, Iraq and Pakistan.

Blindness is an economic burden due to lost productivity and the costs of rehabilitation and education, especially in developing countries (1). Since cataract is the major cause of avoidable blindness, its timely diagnosis and treatment is very important. Cataract surgery is one of the most cost-effective health-care interventions (2). In the Islamic Republic of Iran, the operation is offered in the public and private sectors. The public sector includes mainly university-affiliated centres, non-university centres (military or charity) and surgery centres affiliated with the Iranian national Social Security Organization. Patients referring to these centres are often covered by health insurance or the Social Security Organization. In the private sector, however, expenses are mostly paid out-of-pocket.

In 2010, cataract surgery centres were available in all provinces of the Islamic Republic of Iran. About 43.1\% of the national health expenditure was allocated to the public sector in 2006, while in 2010 the rate was $40.2 \%$. For the private sector, the share of health expenditure increased from $56.8 \%$ in 2006 to $59.8 \%$ in 2010 (3). However, these expenditures are not allocated exclusively to eye surgery services, but to the whole health sector. If we could determine sector-specific expenditures, we would be able to demonstrate the impact of this reduction on the public sector.

In this study, we aimed to compare the contributions of the public and private hospital sectors to the cataract surgery output in 2010 and to the 5-year trends from 2006-10.

\section{Methods}

This study was part of the Iranian Cataract Surgery Survey in which information about cataract surgeries performed at surgical centres throughout the nation were extracted from patient records. Data extraction was conducted by a team of 10 trained personnel under the supervision of an ophthalmologist.

The study methods have been described in a previous report (4). In brief, the list of cataract surgical centres was provided by the Iranian Ministry of Health, Treatment and Medical Education. After categorization of public and private centres, we randomly selected a proportional number of them using Microsoft Excel software and the RANDBETWEEN (bottom, top) command without any replacement. The weights of each sector were determined based on the number of selected centres in each sector.
The Persian calendar is a solar seasonal one tied to the vernal equinox. To assign time frames, after excluding the first 2 weeks of spring (i.e. the first 2 weeks of the year), which are national holidays, 1 week per season was randomly selected for each unit using the above method with replacement. Then the records of all cataract surgeries conducted during these weeks were reviewed. The total number of surgeries in each season was thus determined and multiplied by $50 / 4$ (12.5) to calculate the annual number of surgeries for any given year.

\section{Results}

In 2010, there were 160 public and 81 private cataract surgery centres in the Islamic Republic of Iran. Of these, 77 public (weight: 2.08) and 60 private (weight: 1.35) centres were sampled for the survey. In that year a total of 516273 surgeries were performed at the sampled centres: 318289 (61.7\%) in the public sector and 197984 (38.3\%) in the private sector (Table 1). The private centres' share of national cataract surgeries was 30.4\% in 2006 and this increased to $38.3 \%$ in 2010 . A corresponding decrease in the public centres' share was seen from $69.6 \%$ in 2006 to $61.7 \%$ in 2010 (Table 1).

Table 1 and Figure 1 show the trend in cataract surgery operations over the study period (2006-10). The total number of surgeries performed rose from 324508 in the year 2006 to 516273 in

\begin{tabular}{|c|c|c|c|c|c|}
\hline \multirow[t]{3}{*}{ Year } & \multicolumn{5}{|c|}{ Cataract surgeries performed } \\
\hline & \multirow{2}{*}{$\begin{array}{l}\text { Total } \\
\text { No. }\end{array}$} & \multicolumn{2}{|c|}{$\begin{array}{l}\text { Public sector centres } \\
\qquad(n=77 / 160)\end{array}$} & \multicolumn{2}{|c|}{$\begin{array}{l}\text { Private sector centres } \\
\qquad(n=60 / 81)\end{array}$} \\
\hline & & No. & $\%$ & No. & $\%$ \\
\hline 2006 & 324508 & 225770 & 69.6 & 98738 & 30.4 \\
\hline 2007 & 366549 & 247494 & 67.5 & 119055 & 32.5 \\
\hline 2008 & 459367 & 303002 & 66.0 & 156365 & 34.0 \\
\hline 2009 & 449826 & 280595 & 62.4 & 169231 & 37.6 \\
\hline 2010 & 516273 & 318289 & 61.7 & 197984 & 38.3 \\
\hline
\end{tabular}




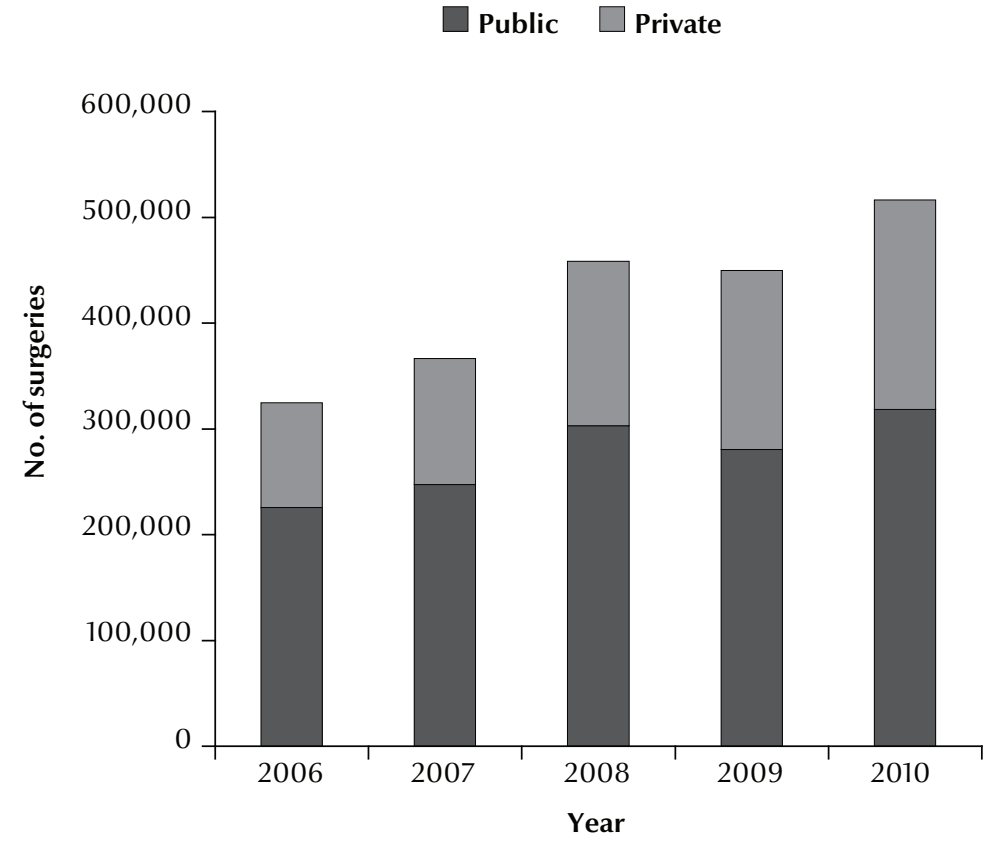

Figure 1 Number of cataract surgeries performed in the public and private sectors in the Islamic Republic of Iran, 2006-2010

the year 2010, a 59.1\% increase. Analysis of the relative contributions of the public and private sectors to the increase showed that in the public centres there was a $41.0 \%$ increase in the number of surgeries from 225770 to 318289 over the 5-year period, while in private centres surgeries rose $100.5 \%$ from 98738 to 197984. Thus, the rise in the number of cataract surgeries was 2.7 times greater in private centres compared with public ones.

\section{Discussion}

"Vision 2020: the right to sight" was launched by the World Health Organization and the International Agency for the Prevention of Blindness with the goal to eliminate avoidable blindness by 2020 (5). Cataract is the leading cause of avoidable blindness, and the rate of blindness due to cataract has a wide range across different parts of the world (6). In developed countries, the onset of cataract is typically after the age of 50 years, but it tends to start at younger ages in developing countries (7). Cataract surgery is a successful and cost-effective intervention for this condition and can enhance patients' quality of life $(8,9)$.

The results of the present study indicated that public centres take on a greater share of service provision than private ones. The public sector's greater share may be due to the high number of university centres, the favourable distribution of these centres and the presence of training resident surgeons in universities. In addition, the Social Security Organization has a $58 \%$ population coverage (10) and plays a major role either directly or through other public services. On the other hand, we saw a $59.1 \%$ increase in the number of cataract surgeries over the 5-year period of the study, which was greater in the private than the public sector. During these years, the national income per person has increased 16.7fold (11) and the purchasing power parity, i.e. the gross domestic product, has increased by 1.8 -fold (12). This could be one explanation for the increased service uptake in the private sector.

During the 5-year study period, there was a $41.0 \%$ increase in cataract surgeries in the public sector, while the over 50-year-old population, which is susceptible to cataract, increased by $35.9 \%$
(11). Therefore, services seem to have increased proportionate to the growth of the susceptible population. Appropriate policy-making and planning is needed to improve and maintain this balance. Nonetheless, studies have reported relatively long waiting times for surgery at Iranian university hospitals (13-15). To our knowledge, there is no report concerning waiting times for cataract surgery in the Islamic Republic of Iran. The list from the Iranian Ministry of Health showed that private cataract surgery services are well-distributed throughout the country. Although the number of private centres was around half that of the public ones, their cataract surgery rate showed a more than $100 \%$ growth during this 5 -year period. This growth is not proportionate with the growth in the population of over-50-year-olds. However, an advantage of increased service provision in this sector is reduced waiting time and the possibility of having surgery shortly after diagnosis. Extensive needs assessment surveys are required to determine the capacity needed for cataract surgery in the private sector.

\section{Conclusion}

The public sector in the Islamic Republic of Iran makes a larger contribution to cataract surgery service provision than the private sector, and its growth is not proportionate to the over-50-year-old population growth. Operations in the private sector, however, seem to show a trend towards a greater share of the total of operations, but this growth needs to be proportionate with the needs of the nation and the elderly population of the country.

\section{Acknowledgements}

Funding: This research was supported by the noncommunicable disease unit of the Iranian Ministry of Health, Treatment and Medical Education

Competing interests: None declared. 


\section{References}

1. Khairallah M, Kahloun R, Flaxman SR, Jonas JB, Keeffe J, Leasher J, et al.; Vision Loss Expert Group. Prevalence and causes of vision loss in North Africa and the Middle East: 1990-2010. Br J Ophthalmol. 2014 May;98(5):605-11. PMID:24590555

2. VISION 2020: the right to sight [Internet]. London: International Agency for the Prevention of Blindness (http://www. iapb.org/vision-2020, accessed 25 June 2015).

3. Global Health Expenditure Database. Iran (Islamic Republic of) - national expenditure on health (Iranian rial) [Internet]. Geneva: World Health Organization (http://apps.who.int/ nha/database/StandardReport.aspx?ID=REP_WEB_MINI TEMPLATE_WEB_VERSION\&COUNTRYKEY=84605, accessed 25 June 2015).

4. Hashemi H, Rezvan F, Khabazkhoob M, Gilasi H, Etemad K, Mahdavi A, et al. Trend in cataract surgical rate in Iran provinces. Iran J Public Health. 2014 Jul;43(7):961-7. PMID:25909063

5. Pizzarello L, Abiose A, Ffytche T, Duerksen R, Thulasiraj R, Taylor H, et al. VISION 2020: The Right to Sight: a global initiative to eliminate avoidable blindness. Arch Ophthalmol. 2004 Apr;122(4):615-20. PMID:15078680

6. Pascolini D, Mariotti SP. Global estimates of visual impairment: 2010. Br J Ophthalmol. 2012 May;96(5):614-8. PMID:22133988

7. Clyton R, Cuthbert J, Seth J, Phillips Cl, Bartholomew RS, Reid JM. Epidemiological and other studies in the assessment of factors contributing to cataractogenesis In: Nugent J, EWhelan J, editors. Human cataract formation. Ciba Foundation symposium 106. London: Pitman; 2009, pp. 18-47. (http://onlinelibrary.wiley.com/doi/10.1002/9780470720875.fmatter/pdf, accessed 25 June 2015).
8. Asgari S, Hashemi H, Nedjat S, Shahnazi H, Fotouhi A. Persian version of the 25-item National Eye Institute visual functioning questionnaire (NEI-VFQ 39): a validation study. Iran J Ophthalmol. 2011;23(3):5-14.

9. Asgari S, Hashemi H, Nedjat S, Shahnazi A, Fotouhi A. Quality of life in the group of patients with chronic eye disease. Iran J Epidemiol. 2011;7(4):43-8.

10. Coverage of Social Security Organization. Tehran: Social Security Organization; 2011 (http://en.tamin.ir/, accessed 25 June 2015).

11. Iran Statistical Year Book [Internet]. Tehran: Statistical Center of Iran; 2011. (http://www.amar.org.ir/Default.aspx?tabid=1604, accessed 25 June 2015) [in Persian].

12. GDP per capita (current US \$) [Internet]. Washington (DC): The World Bank (http://data.worldbank.org/indicator/ NY.GDP.PCAP.CD/countries/IR?display=graph, accessed 25 June 2015).

13. Maleki M, Riahi L, Dashti T, Karbasian S. Reducing waiting time in patients undergone spinal surgeries at operation's room of Shohada-ye-Tajrish hospital using six sigma model. N Y Sci J. 2013;6(12):136-41.

14. Besharati M, Shoja M, Kheirandish M, Shirani L, Parizi Z. Traumatic visual loss of inpatients in Yazd, Iran from 2005 to 2006. Int J Ophthalmol. 2009;2(2):165-7.

15. Tabibi SJ, Najafi B, Shoaie S. Waiting time in the emergency department in selected hospitals of Iran University of Medical Sciences in 2007. Pejouhesh. 2009;33(2):117-22 [in Persian]. 